\title{
Anemia of Chronic Renal Failure
}

\author{
CHARLES L. SEXAUER, M.D. and JAMES R. MATSON, M.D. \\ University of Oklahoma Health Sciences Center, \\ Oklahoma City, OK 73190
}

\begin{abstract}
Anemia is one of the most characteristic and visable manifestations of chronic renal failure. Investigators in the past decade have provided a better understanding of this anemia. The etiology of the anemia of chronic renal failure has three facets: first is reduced erythropoietin production by damaged kidneys; second is the presence of inhibitors to red blood cell ( $\mathrm{RBC}$ ) production in uremic serum; and third is red blood cell hemolysis.

Unfortunately, transfusion therapy with its expense and risk of transmissable viral disease remains the mainstay of management for symptomatic anemia. Other modalities include dialysis, androgens, histidine supplementation, and erythropoietin replacement.
\end{abstract}

Anemia is one of the most characteristic and visible manifestations of chronic renal failure. In 1836, Bright ${ }^{1}$ first commented on the pallor patients with renal disease; since then, many investigators have attempted to characterize and explain the underlying anemia.

The kidney has two major functions, excretory and endocrine. As an excretory organ, the kidney clears the body of excess solute, water and metabolic waste. As an endocrine gland, it produces 1.25 dihydroxy vitamin $\mathrm{D}$, the active metabolite of vitamin $D$, and erythropoietin, the major hormone modulating red blood cell produced by bone marrow. The common pathophysiologic character of progressive kidney disease is the destruction of renal mass and loss of both excretory and endocrine function. Short of kidney allografts, satisfactory compensation for lost excretory function is available through dialysis. Equally satisfactory compensation for lost endocrine function is lacking. While new semi-synthetic analogues of the active form of vitamin D have significantly reduced morbidity of renal osteodystrophy, no such advances have been made in the management of the anemia of chronic renal failure.

Investigators in the past decade have provided a better understanding of the anemia of chronic renal failure, and this understanding will help clarify the therapeutic dilemma.

The cause of anemia in chronic renal failure has at least three facets. First is the reduced erythropoietin production by damaged kidneys. Radtke and associates ${ }^{16}$ have shown that as renal damage pro- 
gresses, the hematocrit remains unchanged until the creatinine clearance drops below $40 \mathrm{ml}$ per min per $1.73 \mathrm{M}^{2}$ Below this value, the creatinine clearance and the hematocrit are positively correlated. Serum erythropoietin increases over normal values as renal damage progresses and reaches a peak at a creatinine clearance of 20 to $29 \mathrm{ml}$ per min per $1.73 \mathrm{M}^{2}$, declining thereafter but with previous values found in normal individuals. Caro and associates ${ }^{2}$ demonstrated that the erythropoietin levels in patients with chronic renal failure who have kidneys are higher than in those without kidneys, albeit not as high as in subjects without renal disease who have anemia of equivalent severity. Thus, the deficiency of erythropoietin is relative to an increased demand for RBC production for which the elevated levels are not adequate.

The second facet of this anemia is the presence of inhibitors to red blood cell ( $R B C)$ production in uremic serum. Moriyama and Fisher $^{13}$ have shown in uremic rabbit marrow that erythropoietin-responsive stem cells are present in increased numbers and that they are normally responsive to erythropoietin. These authors suggested that the anemia was not due to failure of stem cells to respond to erythropoietin, but that $\mathrm{RBC}$ production was inhibited at a later step, possibly heme synthesis. This contention was subsequently supported by Wallner and associates ${ }^{23}$ who demonstrated that sera from uremic patients inhibited the incorporation of ${ }^{59} \mathrm{Fe}$ into heme in dog marrow. This inhibition could not be related to urea, creatinine, or guanidino succinic acid. More recently, Ohno et $\mathrm{al}^{14,15}$ and Freedman and Saun$\operatorname{ders}^{6}$ have reported inhibitors to both bone marrow erythroid colony forming cells (CFU-E* and BFU-E $\nmid$ ) in the sera of uremic rabbits and patients, which are

\footnotetext{
* Colony-forming units-erythroid.

f Burst-forming units-erythroid.
}

partially removed by hemodialysis. It has yet to be determined whether or not the inhibitors reported for heme synthesis are identical to those reported for CFU-E and BFU-E. Thus, while erythropoietin does decline in advanced renal failure, it remains higher than normal. Even these elevated levels are not adequate in the face of severe anemia and may reflect a pathologically reduced erythropoietin secretory response from diseased renal tissue. While primitive stem cells remain responsive to erythropoietin, effective erythropoiesis does not occur owing to inhibitors of CFU-E, BFU-E, and heme synthesis.

Finally, in the uremic environment, the RBC have a shortened life span. Shaw, ${ }^{20}$ using chromium-5l tagged red cells, demonstrated a reduced circulating halftime in uremic patients. Since the red blood cells from uremic patients survive normally when injected into healthy recipients, and since normal red cells have a shortened life span in uremic recipients, ${ }^{4,18}$ it appears that a factor in the metabolic environment is unfavorable to red cells. Indeed, changes in overall red cell metabolism, ${ }^{25}$ in the hexose monophosphate shunt, ${ }^{26}$ in the membrane ATPase, ${ }^{3}$ and in glutathione stability ${ }^{21}$ have been described in red cells suspended in plasma from uremic patients.

Giovannetti et al ${ }^{9,10,11}$ have recently demonstrated that guanidine derivatives, especially methylguanidine, are elevated in the sera of uremic patients, produce anemia in dogs at levels comparable to those seen in uremic patients, and dialyze quite differently as compared to urea and creatinine. These investigations have postulated a role for methylguanidine in the shortened red cell life span in chronic uremia.

Unfortunately, transfusion therapy with its expense and risk of transmissable viral disease for patients and dialysis unit personnel remains the mainstay of management for symptomatic anemia. Other 
modalities include dialysis, androgens, histidine supplementation, and erythropoietin replacement.

Patients started and continued on dialysis for several months experience an increase in hematocrit. Radtke and associates ${ }^{17}$ have shown that this increase in hematocrit was associated with reduced levels of erythropoietin making improved secretion of the renal hormone an unlikely cause of improvement. Removal of a dialyzable inhibitor of RBC production has been suggested as the reason for the observed improvement.

Androgen therapy has been reported by several authors ${ }^{12,19,7,24}$ to improve anemia in chronic renal failure. As in other forms of anemia, the mechanism is not known. Androgens have not become widely accepted because their virilizing effects are often unacceptable to female patients and hepatic dysfunction, a common side effect, is a greater problem in this population at risk for hepatitis.

Serum histidine levels are reduced in uremic subjects. Giordano and associates ${ }^{8}$ studied a group of uremic patients who received a histidine dietary supplement. A significant improvement in hematocrit was noted following addition of supplemental histidine. It is unclear if the mechanism is simply one of dietary repletion or if some more specific effect is responsible for the increased hematocrit. While histidine supplementation has no known untoward effects, its use has not become widespread.

Erythropoietin replacement is generally regarded as the most promising potential therapeutic modality. ${ }^{5} \mathrm{~A}$ major difficulty with currently available preparations is contamination with endotoxin, which has limited investigation to in vitro and animal work. Van Stone and $\mathrm{Max}^{22}$ used erythropoietin in nephrectomized rats maintained on hemodialysis. This species is resistant to the effects of endotoxin. While nephrectomized rats treated with erythropoietin had a signifi- cantly larger red cell mass than nephrectomized untreated rats, the hematocrit and the red cell mass remained less than those of sham operated controls.

Another major difficulty with the potential use of erythropoietin as a therapeutic agent is that the assay of this material is not standardized and, therefore, there is no assurance that commercial preparations will be potent and effective in stimulating human marrow progenitors.

Thus, while erythropoietin does have great potential for the amelioration of anemia, the presence in uremic serum of inhibitors of erythropoiesis ${ }^{23}$ and lack of correlation between the hematocrit and erythropoietin in dialysis patients ${ }^{16}$ indicate erythropoietin replacement may not be totally adequate. New techniques in dialysis to remove the inhibitors of erythropoiesis and the discovery of erythropoietically active steroids, which lack the masculinizing and other deleterious effects of androgens, remain other promising areas of further research.

\section{References}

1. BRIGHT, R.: Cases and observations, illustrative of renal disease accompanied with the secretion of albuminous urine. Guys Hosp. Rep. $1: 340$, 1836.

2. Caro, J., Brown, S., Miller, O., Murray, T., and ERSLEV, A. J.: Erythropoietin levels in uremic nephric and anephric patients. J. Lab. Clin. Med. 93:449-458, 1977.

3. Cole, C. H., Balfe, J. W., and Welt, L. G.: Induction of an ouabain sensitive ATPase defect by uremic plasma. Trans. Assoc. Amer. Physicians 9:173-177, 1977.

4. Desforges, J. F. and Dawson, J. P.: The anemia of renal failure. Arch. Intern. Med. $101: 326-329,1958$.

5. Fisher, J. W.: Mechanism of the anemia of chronic renal failure. Nephron 25:106-111, 1980.

6. Freedman, M. H. and Saunders, E. F.: Erythroid stem cell studies in chronic renal disease. 16th International Congress on Hematology, Kyato, 1976, p. 6.

7. Fried, W., Jonasson, O., Lang, G., and SCHwARTZ, F.: The hematologic effect of androgen in uremic patients. Ann. Intern. Med. 79:823-827, 1973.

8. Giordano, C., De Santo, N. G., Runaldi, $S$, ACONE, D., Esposito, R., and Gallo, B.: His- 
tidine for treatment of uraemic anaemia. Brit. Med. J. 4:714-716, 1973.

9. Giovannettr, S., Balestri, P. L., and BARSOTTI, G.: Methylguanidine in uremia. Arch. Intern. Med. 131:709-713, 1973.

10. Giovannetti, S. and Barsotti, G.: Dialysis of methylguanidine. Kidney Int. 6:177-183, 1974.

11. Giovannetti, S., Crane, L., Balestic, L., and BARGINI, M.: Evidence that guanidines and some related compounds cause haemalysis in chronic uremia. Clin. Sci. 34:141-148, 1968.

12. Hendler E. D., Goffinet, J. A. Ross., S., LONGNECKER, R. E., and BAKovic, V.: Controlled study of androgen therapy in anemia of patients on maintenance hemodialysis. New Eng. J. Med. 291:1046-1051, 1974.

13. Moruyama, Y. and Fisher, J. W.: Effects of erythropoietin on erythroid colony formation in uremic rabbit bone marrow cultures. Blood 45:659-664, 1975.

14. OHNO, Y. and Fisher, J. W.: Inhibition of bone marrow erythroid colony forming cells (CFU-E) by serum from chronic anemic uremic rabbits. Proc. Soc. Exp. Biol. Med. 156:56-59, 1977.

15. Ohno, Y., Rege, A. B., Fisher, J. W., and BARONA, J.: Inhibitors of erythroid colony forming cells (CFU-E and BFU-E) in sera of azotemic patients with anemia of renal disease. J. Lab. Clin. Med. 92:916-923, 1978.

16. Radtke, H., Claussner, A., Erbes, P., ScheuermanN, E., Schoeppe, W., and Koch, $\mathrm{K}$.: Serum erythropoietin concentration in chronic renal failure: Relationship to degree of anemia and excretory renal function. Blood 54:877-884, 1979.

17. Radtke, H. W., Frei, U., Erbes, P. M., SCHOEPPE, W., and KOCH, K. M.: Improving anemia by hemodialysis: Effect on serum erythropoietin. Kidney Internat. 17:382-387, 1980.

18. Ragen, P. A., Hagedon, A. B., and Owen, C. A.: Radioisotope study of anemia in chronic renal disease. Arch. Int. Med. 105:518-522, 1960.

19. Richardson, J. R., JR. and Weinstein, M. B.: Erythropoietic response of dialyzed patients to testosterone administration. Ann. Int. Med. 73:403-407, 1970 .

20. SHAw, A. B.: Haemolysis in chronic renal failure. Brit. Med. J. 2:213-216, 1967.

21. Theil, G. B., Brodine, C. E., and Doolan, P. D.: Red cell glutathion content and stability in renal insufficiency. J. Lab. Clin. Med. 58:736, 1961.

22. Van Stone, J. C. and MAX, P.: Effect of erythropoietin on anemia of peritoneally dialyzed anephric rats. Kidney Internat. 15:370-375, 1979.

23. WALlner, S. F., Kurnick, J. E., Ward, H. P., VAUTRIN, R., and ALFREY, A. C.: The anemia of chronic renal failure and chronic disease: In vitro studies of erythropoiesis. Blood 47:561$569,1976$.

24. Williams, J. S., Stein, J. H., and FerRIS, T. F.: Nandrolone decanoate therapy for patients receiving hemodialysis. Arch. Intern. Med. 134:289-292, 1974.

25. WARLE, E. N.: A study of the effects of possible toxic metabolities of uremia on red cell metabolism. Acta Haemat. 43:129-132, 1970.

26. YawatA, J., Howe, R., and JACOB, H. S.: Abnormal red cell metabolism causing hemolysis in uremia: A defect potentiated by tap water hemodialysis. Ann. Intern. Med. 79:362-366, 1973. 